NBER WORKING PAPER SERIES

\title{
DIFFERENT TYPES OF CENTRAL BANK INSOLVENCY AND THE CENTRAL ROLE OF SEIGNORAGE
}

\author{
Ricardo Reis \\ Working Paper 21226 \\ http://www.nber.org/papers/w21226 \\ NATIONAL BUREAU OF ECONOMIC RESEARCH \\ 1050 Massachusetts Avenue \\ Cambridge, MA 02138 \\ May 2015
}

This note was delivered as a discussion of "When does a central bank's balance sheet require fiscal support?" by Marco Del Negro and Christopher A. Sims at the Carnegie-Rochester conference of November, 2014. I am grateful to the Institute for New Economic Thinking for financial support, and to Cynthia Balloch, Jens Hilscher and Alon Raviv for comments. The views expressed herein are those of the author and do not necessarily reflect the views of the National Bureau of Economic Research.

The author has disclosed a financial relationship of potential relevance for this research. Further information is available online at http://www.nber.org/papers/w21226.ack

NBER working papers are circulated for discussion and comment purposes. They have not been peerreviewed or been subject to the review by the NBER Board of Directors that accompanies official NBER publications.

(C) 2015 by Ricardo Reis. All rights reserved. Short sections of text, not to exceed two paragraphs, may be quoted without explicit permission provided that full credit, including $(\mathbb{C}$ notice, is given to the source. 
Different Types of Central Bank Insolvency and the Central Role of Seignorage

Ricardo Reis

NBER Working Paper No. 21226

May 2015

JEL No. E42,E58,E59

\begin{abstract}
A central bank is insolvent if its plans imply a Ponzi scheme on reserves so the price level becomes infinity. If the central bank enjoys fiscal support, in the form of a dividend rule that pays out net income every period, including when it is negative, it can never become insolvent independently of the fiscal authority. Otherwise, this note distinguishes between intertemporal insolvency, rule insolvency, and period insolvency. While period and rule solvency depend on analyzing dividend rules and sources of risk to net income, evaluating intertemporal solvency requires overcoming the difficult challenge of measuring the present value of seignorage.
\end{abstract}

\title{
Ricardo Reis
}

Department of Economics, MC 3308

Columbia University

420 West 118th Street, Rm. 1022 IAB

New York NY 10027

and NBER

rreis@columbia.edu 


\section{Introduction}

There is no bankruptcy procedure for a central bank, that is, there is no institution that will judge if a central bank's debts exceed its liabilities and force it to reorganize or to be liquidated. Moreover, if any private agent wants to settle a claim that it has on the central bank, or is willing to sell it a good or asset, then as long as the claim or price are denominated in units of currency, the central bank will always be able to pay. The central bank can print currency, which is legal tender to settle any debts and buy any goods.

These two observations are correct and important. Yet, they have led far too many commentators and researchers to jump to the conclusion that a central bank cannot become insolvent. Like any other economic agent, central banks face a resource constraint that limits their actions. Central banks may be able to print money, but they cannot conjure up free lunches.

If the central bank makes plans that involve using more resources than the ones that it has available, the central bank will be insolvent. Just like a consumer in standard economic theory, this insolvency will reflect itself in the central bank trying to run a Ponzi scheme. The only way to indefinitely persist in using more resources than the ones that are available is to borrow from other agents and keep on rolling over this debt. Yet, being offered this

deal, no other agent will choose to accept it. The real value of a bond behind a Ponzi scheme is zero.

What is special about central banks is that their liabilities, currency and reserves, define the unit of account in the economy. A unit of reserves that is deposited by commercial banks in the central bank can at any point be redeemed for a unit of currency that is worth $\$ 1$. Therefore, the real value of a unit of reserves is the inverse of the price level. Insolvency then means that reserves and currency denominated in the old unit of account become worthless, or that there is hyperinflation and/or currency reform. The unexpected burst 
in inflation, or the conversion rate between old and new currency after a currency reform, are the counterparts of the recovery rate on debt in an insolvency process. Insolvency of a central bank is then not just theoretically possible: it is also frequent in practice across the world, as attested by the multiple currency reforms that have taken place.

\section{Fiscal support, fiscal backing, and central bank in- dependence}

A central bank is just one of many government agencies. Insofar as its liabilities are supported by the fiscal authorities, the central bank cannot be insolvent separately from the solvency of the overall government.

To give an example, the Department of Transportation (DoT) in most countries uses many resources and generates very few. Yet, every year, the Treasury provides fiscal support by transferring the needed resources to the DoT. The DoT is never insolvent separately from the Treasury, since whatever debts it takes on will be honored by the Treasury.

Likewise, a central bank that enjoys fiscal support will never be insolvent separately from the Treasury. Most of the time, the central bank earns a profit and rebates it in full to the Treasury. Other times, it will make losses, but as long as the Treasury likewise transfers the amount in loss to the central bank, the central bank is never independently insolvent.

Fiscal support is not the same as fiscal backing, as Del Negro and Sims (2015) emphasize. The latter refers to fiscal policy being set in a way that is consistent with the central bank's pursuit of its inflation target. A long literature has established time and again (Woodford, 2003) that for the price level to be uniquely determined requires a minimum amount of backing by the fiscal authorities, in the sense of adjusting primary surpluses to pay down existing nominal debts in a way that is consistent with the inflation target of the monetary 
authorities. Whether there is fiscal backing or not, there may or may not be fiscal support. ${ }^{1}$

One way to ensure fiscal support is to follow the example of the Bank of England in 2009, and have the central bank hold its risky assets in an account that is fully indemnified by the Treasury. This way, losses are automatically borne by the Treasury. Another, more general way, is to adopt a central bank charter that allows for negative dividends. Either way, these should not be mischaracterized as recapitalizations of a weak central bank that is no longer independent from the Treasury. As long as there is a clear rule that is automatically applied, without relying on discretionary transfers from the Treasury, then a fiscally supported central bank is solvent.

In principle, it could be hard to characterize the rule or evaluate circumstances under which a central bank is solvent. However, Hall and Reis (2015) prove that there is a clear rule that ensures solvency, and that it is quite close to the existing charter of many central banks. It simply states that every period the central bank should calculate its net income, marking assets to market, and rebate it in full to the Treasury if it is positive, or receive a transfer in this amount from the fiscal authority if it is negative. The Federal Reserve or the ECB already follow this rule when it comes to rebating positive net income every year, but the extent to which the fiscal authorities are committed to transfers that cover episodes of negative net income is less clear. Therefore, the fiscal support of these major central banks is currently incomplete, and their solvency is, at least theoretically, potentially at risk. The literature on this topic has discussed different forms of insolvency.

\footnotetext{
${ }^{1}$ While the distinction is clear in the literature, the terms are not: Reis (2013a), Berriel and Mendes (2015), Benigno and Nistico (2015), and Hall and Reis (2015) all use fiscal backing to describe what Del Negro and Sims (2015) call fiscal support, and use the conventional terms of Ricardian or passive fiscal policy for what Del Negro and Sims (2015) call fiscal backing.
} 


\section{Three types of insolvency: period, rule, and intertem- poral}

Without fiscal support, a central bank is insolvent whenever its actions lead to explosive growth in reserves, violating a no-Ponzi scheme condition. Still, depending on how fiscal support is limited, there can be different types of insolvency.

It will be useful to introduce some notation. Following Reis (2013b), we can write the resource constraint of the central bank at date $t+1$ as:

$$
h_{t+1}+v_{t+1}=h_{t}+\left(1+i_{t}\right) v_{t}+a_{t}-\sum_{j=1}^{J}\left(1+i_{t+1}^{j}\right) a_{t}^{j}+p_{t+1} d_{t+1}+x_{t+1} \text {, }
$$

where $h_{t}$ is currency and non-interest paying required reserves, $v_{t}$ are interest-paying excess reserves that remunerate banks at the safe rate $i_{t}, a_{t}^{j}$ are the central bank holdings of poten-

tially $J$ different assets each earning a risky return $i_{t+1}^{j}$ with their total amount $a_{t}=\sum_{j} a_{t}^{j}$. Then, $d_{t}$ is the real dividend paid to the Treasury, and $x_{t+1}$ are the nominal expenses of running the central bank.

The no-Ponzi scheme condition on reserves states that:

$$
\lim _{T \rightarrow \infty} \mathbb{E}_{t}\left[m_{t, T}\left(\frac{a_{T}-v_{T}}{p_{T}}\right)\right] \geq 0,
$$

where $m_{t, t+j}$ is the stochastic discount factor that at date t values real payoffs at date $t+j$.

\subsection{Period insolvency}

Imagine that the central bank records a negative net income in a period. If the Treasury refuses to make a transfer in that amount, then the central bank must borrow the amount of this loss via extra reserves. When the central bank next earns a positive net income, it 
would like to use it to retire those extra reserves. But, if the Treasury demands to be paid, then reserves will drift to infinity, and the central bank will be insolvent.

This result, due to Hall and Reis (2015), shows that with this extreme lack of fiscal support, the central bank will become insolvent as soon as it records even one year of negative net income. When does this happen?

Under the textbook model of a central bank, that issues no reserves and holds no assets $\left(a_{t}=v_{t}=0\right)$, net income every period is just equal to seignorage minus expenses:

$$
d_{t+1}=\frac{h_{t+1}-h_{t}-x_{t+1}}{p_{t+1}} .
$$

While in any given week or month, this may be negative, in the space of a year it rarely is. The amount of currency in circulation has a trend growth rate and this ensures a positive steady flow of seignorage.

Before the financial crisis, the Federal Reserve almost entirely held as assets safe shortterm government bonds, and conducted open-market operations exchanging reserves or currency for bonds, so that the difference $a_{t}-h_{t}-v_{t}$ was roughly constant. In that case:

$$
p_{t+1} d_{t+1}=i_{t}\left(a_{t}-v_{t}\right)-x_{t+1} .
$$

Since the expenses of the central bank are typically negligible, even with a relatively small balance sheet, dividends are always positive. This convention leads also to a simple and transparent rule, where the central bank rebates to the Treasury every year the interest that it earns on its holdings of Treasury bonds minus reserves after deducting expenses.

However, under new-style central banking, central banks hold assets that are of longer maturity, can default, or are denominated in foreign currency. These expose the central bank to interest rate, default or currency risk, respectively. Hall and Reis (2015) show that net income can then easily be negative, and give a few examples. For the Fed, this might happen 
when interest rates rise at the end of a crisis, causing a capital loss on bond holdings. For the ECB, it might happen if some of the government bonds that it holds unexpectedly default on their coupon or principal payments. And for the central banks of small open economies, it may happen in the course of defending an exchange rate peg.

\subsection{Rule insolvency}

Hall and Reis (2015) instead define insolvency in terms of whether the central bank can stay committed to the rule for dividends in its charter without reserves exploding. This may be equivalent to period insolvency if the rule implies that dividends can never be negative, the extreme lack of fiscal support case that I just explained. But it is more general than that, and more grounded to the key concept of fiscal support, by emphasizing the role of the rule for dividends that fiscally connects the central bank and the Treasury.

The Federal Reserve's rule allows it to run a deferred account, whereby periods of negative net income are recorded into the account, and the Fed can withhold payments to the Treasury when positive net income resumes, until the account is drawn down to zero. Hall and Reis (2015) show that in this case, the balance in the deferred account, or the number of years that are expected to take for its balance to get to zero, are two useful quantifiable measures of central bank solvency. Hall and Reis (2015) and Carpenter et al. (2015) provide simulations

for the Federal Reserve suggesting that it seems far from being insolvent, while Goodfriend (2014) argues that retaining earnings would have been preferable.

\subsection{Intertemporal insolvency}

Reis (2013b) instead proposed measuring solvency from an intertemporal perspective. Iterating equation (1) forward to infinity and using the no-Ponzi scheme condition (2) gives the 
intertemporal budget constraint:

$$
\mathbb{E}_{t} \sum_{j=1}^{\infty} m_{t, t+j} d_{t+j} \leq \frac{a_{t}}{p_{t}}-v_{t}+\mathbb{E}_{t} \sum_{j=1}^{\infty} m_{t, t+j} s_{t+j}
$$

On the left-hand side is the present value of dividends, which is bounded above by the value of the balance sheet capital of the central bank (assets minus reserves) plus the present value of seignorage.

Reis $(2013 b)$ then defines a central bank to be solvent as long as the present value of its dividends to the Treasury is non-negative. This is the approach also followed by Bassetto and Messer (2013), Del Negro and Sims (2015), and Hilscher, Raviv and Reis (2015). It is equivalent to rule-solvency in the extreme case when the deferred account's limit is equal to the right-hand side of equation (5). Similarly, if the central bank can engage in creative accounting in calculating its net income so that it turns any positive present value into an infinite stream of non-negative payoffs, then it is equivalent to period solvency. But more generally, a central bank may have occasional periods of negative net income, and may deviate from its charters' rule while still remaining intertemporally solvent.

\subsection{Which of these three definitions is the right one?}

There is no simple answer to this question. It depends on what are the relevant political constraints. If the central bank has full fiscal support, any one of the definitions above applies: the central bank is always solvent. At the next level, if the Treasury only demands that the central bank does not need fiscal support intertemporally, but is willing to support it at any date and allow it to deviate from the charters' rule temporarily, then intertemporal solvency is the adequate constraint. Further, if the Treasury requires that the rules are followed, otherwise threatening the independence of the central bank, then it is rule solvency that applies. And finally, if the Treasury always demands to be paid in full when there is positive 
net income, then it is the very strict period solvency that is applicable.

Importantly, none of these definitions is more economic or better grounded in economic theory or principles than the others. They each correspond to different situations in terms of the political economy between the central bank and the Treasury.

\section{The central role of seignorage}

The upper bound on intertemporal solvency is the sum of balance sheet capital and the present value of seignorage. Balance-sheet capital is quite small for most central banks, so the key term is seignorage.

\subsection{How large is the present value of seignorage?}

Del Negro and Sims (2015) take a simple and transparent approach to answer this question (see also Buiter, 2014). Given their estimates of the demand for currency, average seignorage is $0.23 \%$ of GDP per year. Assuming the economy is in a steady state with fixed velocity, seignorage will be constant. Thus, its present value is just $0.23 \%$ divided by the rate at which future payoffs are discounted.

In a Ramsey economy with log preferences, the discount rate in steady state is equal to the real interest rate minus the constant growth rate of aggregate consumption. Del Negro and Sims (2015) calibrate the real interest rate to $2 \%$ and the growth rate of the economy to $1.75 \%$. As a result, their estimate of the present value of seignorage is $94 \%$ of GDP. With these large resources at its disposal, and less than 15\% of GDP in outstanding reserves, even in the most extreme scenarios it is hard for the central bank to ever become intertemporally insolvent.

However, how reliable is this estimate? Figure 1 plots the transfers from the Fed to the Treasury, between 1960 and 2013, as a ratio of GDP. They averaged $0.28 \%$ of GDP, but 
they were as high as $0.45 \%$ of GDP in 1982 and as low as $0.12 \%$ in 1961. Moreover, there are clear trends in the figure across decades. Assuming a constant value from the present to the indefinite future is only a first pass for a needed more careful study of the properties of seignorage over time.

Moreover, the assumption of a discount rate for future payoffs of $0.25 \%$ is admittedly low. Common textbook assumptions (Barro and Sala-i-Martin, 2003) assume instead that it equals $5 \%$. Taking into account the effect of taxes on capital income, points instead to $2 \%$ as a reasonable number for the discount rate (Reis, 2009). The first would cut the present value of seignorage to $5 \%$ of GDP, and the second to $12 \%$. Moreover, by ignoring that the seignorage payoffs are uncertain and using a safe real return to discount them, all of these calculations overstate the proper risk-adjusted present value of seignorage.

Hilscher, Raviv and Reis (2015) provide a more recent set of estimates. They do not assume a constant real interest rate but instead measure stochastic discount factors at different horizons using options contracts on inflation. Also, they do not assume fixed seignorage or velocity, but use U.S. data to estimate seignorage functions under different identifying assumptions. They provide a range of estimates, but almost all are significantly lower than the value of GDP.

\subsection{How does seignorage depend on inflation?}

As the economy goes through inflation episodes, the present value of seignorage will fluctuate. As a result, the intertemporal solvency of the central bank may sometimes be at risk, depending on the current and expected future values of inflation, including possible "inflation scares" (Goodfriend, 1993).

To pin down these variations, one would need to pin down how seignorage varies with inflation. Yet, this is even harder than pinning down the present value of seignorage. Figure 2 plots data on annual seignorage against inflation for the United States, together with four 
Figure 1: Dividends from the Fed to the Treasury (\% of GDP)

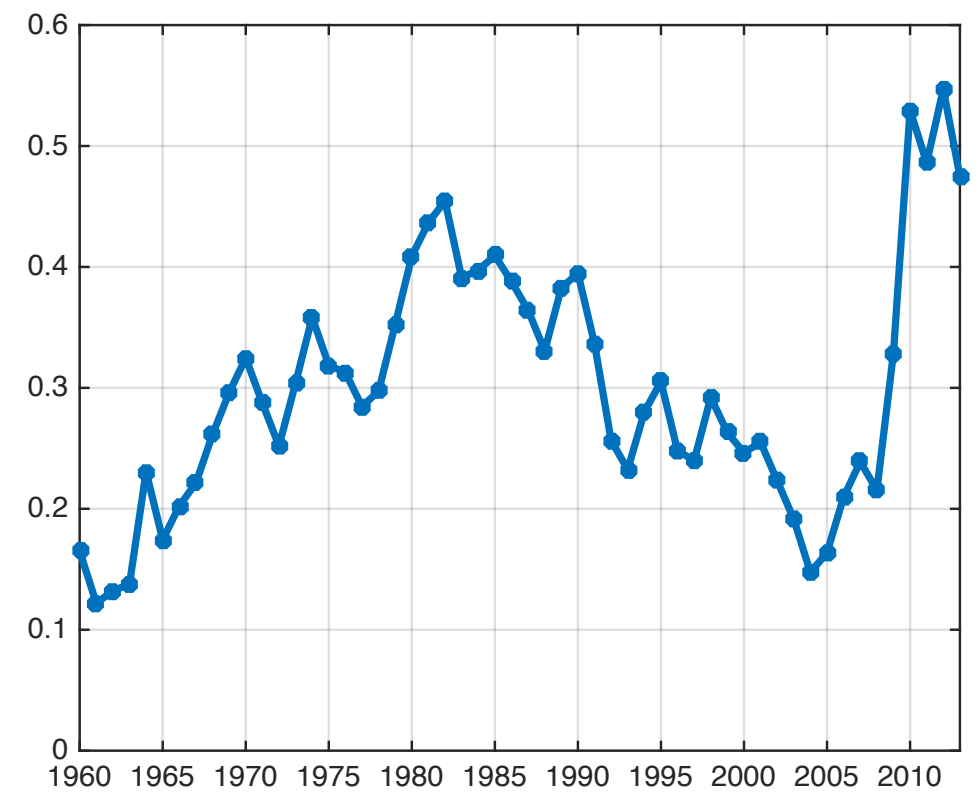

fitted models: (i) the one in Del Negro and Sims (2015) that comes from a linear relation between the level of inverse velocity on log interest rates; (ii) an alternative (and common) log-log specification where log inverse-velocity depends linearly on the log of interest rates (Lucas, 2000); (iii) an also common semi-log specification, where log velocity depends linearly on the level of interest rates (Ball, 2001); and (iv) a specification from a least squares regression of seignorage on leads and lags of inflation in the spirit of Hilscher, Raviv and Reis (2015). All of the specifications are normalized so that they intersect at the point corresponding to average inflation and average seignorage between 1960 and 2013.

While the U.S. observations are almost all for single-digit inflation, the figure extrapolates the models all the way to an inflation rate of $30 \%$. The point is that there is tremendous uncertainty about how annual seignorage will change with inflation. It is very hard to predict what would happen to the solvency of the Fed if there was run-away inflation. Simply, we don't know by how much the holders of US currency (many of whom are foreigners) 
Figure 2: Different models of seignorage (\% of GDP) against inflation

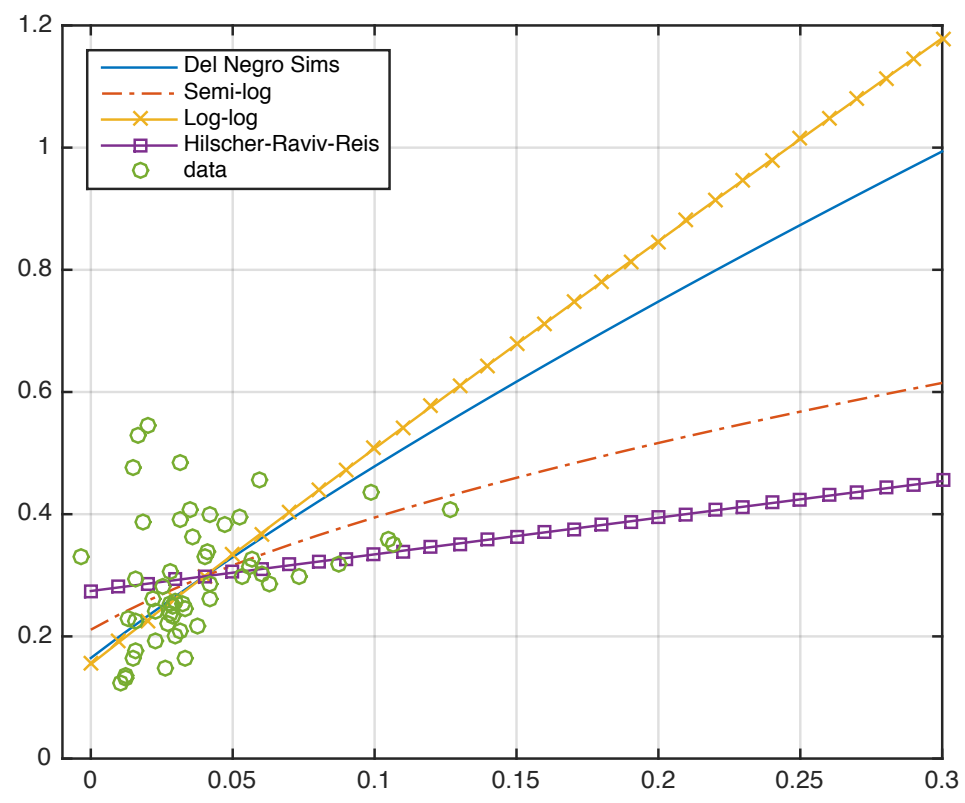

would lower their dollar holdings, and at what point they might switch to other currencies completely.

\subsection{Solvency-driven inflation indeterminacy}

The intertemporal budget constraint of the central bank in equation (5) becomes:

$$
P V(d) \leq \frac{a_{t}}{p_{t}(r+\pi+\delta)}-v_{t}+c_{t} L\left(\frac{\pi+g}{r-g}\right)
$$

under the following set of assumptions. First, that inverse velocity $h_{t} / p_{t} c_{t}$ is constant at $L$ and that the real interest rate, growth rate, and inflation rate are fixed at $r, g$, and $\pi$, respectively. Second, that the portfolio of assets of the central bank consists of zero-coupon nominal bonds with a maturity distribution that is approximately exponential with average maturity $1 / \delta$. Third, that we can approximate the time intervals to continuous time. 
This expression shows that permanently higher inflation, on the one hand, lowers the real value of the nominal bonds that the Fed holds while, on the other hand, it increases the present value of seignorage. Depending on the size of the balance sheet of the Fed $\left(v_{t}\right)$, either the right hand-side can be always positive for positive inflation, or potentially it can be negative in a range between two levels of positive inflation $\left(\pi^{*}, \pi^{* *}\right)$.

In that case, we can turn the study of solvency into a model of inflation. If the central bank is committed to stay intertemporally solvent, then only inflation rates outside of the interval $\left(\pi^{*}, \pi^{* *}\right)$ are consistent with an equilibrium. If the central bank is commanded by the fiscal authorities to deliver a particular level of dividends, say zero for simplicity, then there are two possible equilibria, $\pi^{*}$ and $\pi^{* *}$. Exploring this possible multiplicity of equilibria further is a worthwhile pursuit for future research.

\section{Conclusion}

A recent wave of work clarifies that central banks can become insolvent as long as they are independent and do not have full fiscal support. A central bank is insolvent if it tries to run a Ponzi scheme on its reserves, banks no longer want to hold them, they become worthless, and the price level becomes infinity. If the central bank enjoys fiscal support in the form of a dividend rule whereby it pays out its net income every period, including when it is negative, it can never become insolvent independently of the fiscal authority. While fiscal support is easy to implement in theory, it requires commitment from the Treasury to sometimes transfer funds to the central bank.

Without full fiscal support, this note distinguishes between intertemporal insolvency, when the present value of dividends is negative, rule insolvency, when the central bank cannot stay committed to the rule for dividends in its charter without reserves exploding, and period insolvency, when there is one period of negative net income. Studying period and 
rule solvency requires studying dividend rules and sources of risk to net income. Studying intertemporal solvency requires tackling the difficult challenge of measuring how large the present value of seignorage is and how it varies with inflation.

\section{References}

Ball, Laurence. 2001. "Another look at long-run money demand." Journal of Monetary Economics, 47(1): 31-44.

Barro, Robert J., and Xavier Sala-i-Martin. 2003. Economic Growth. . 2nd Edition ed., The MIT Press.

Bassetto, Marco, and Todd Messer. 2013. "Fiscal Consequences of Paying Interest on Reserves." Fiscal Studies, 34: 413-436.

Benigno, Pierpaolo, and Salvatore Nistico. 2015. "Central Bank Balance Sheet, Liquidity Trap, and Quantitative Easing." LUISS Guido Carli and Sapienza University of Rome.

Berriel, Tiago C., and Arthur Mendes. 2015. "Central Bank Balance Sheet, Liquidity Trap, and Quantitative Easing." PUC-Rio.

Buiter, Willem H. 2014. "Central Banks: Powerful, Political and Unaccountable?" CEPR Discussion Paper 10223.

Carpenter, Seth B., Jane E. Ihrig, Elizabeth C. Klee, Daniel W. Quinn, and Alexander H. Boote. 2015. "The Federal Reserve's Balance Sheet and Earnings: A Primer and Projections." International Journal of Central Banking, 11(2): 237-283.

Del Negro, Marco, and Christopher A. Sims. 2015. "When Does a Central Bank's Balance Sheet Require Fiscal Support?" Journal of Monetary Economics. 
Goodfriend, Marvin. 1993. "Interest rate policy and the inflation scare problem: 19791992." Federal Reserve Bank of Richmond Economic Quarterly, 79(1): 1-23.

Goodfriend, Marvin. 2014. "Monetary Policy as a Carry Trade." Monetary and Economic Studies, 32: 29-44.

Hall, Robert E., and Ricardo Reis. 2015. "Maintaining Central-Bank Solvency under New-Style Central Banking." NBER Working Paper 21173.

Hilscher, Jens, Alon Raviv, and Ricardo Reis. 2015. "Measuring the Market Value of Central Bank Capital." Brandeis University and Columbia University.

Lucas, Robert E. 2000. "Inflation and Welfare." Econometrica, 68(2): 247-274.

Reis, Ricardo. 2009. "The Time-Series Properties of Aggregate Consumption: Implications for the Costs of Fluctuations." Journal of the European Economic Association, 7(4): 722753.

Reis, Ricardo. 2013a. "Central Bank Design." Journal of Economic Perspectives, 27(4): 1744.

Reis, Ricardo. 2013b. "The Mystique Surrounding the Central Bank's Balance Sheet, Applied to the European Crisis." American Economics Review, 103(3): 135-140.

Woodford, Michael. 2003. Interest and prices: foundations of a theory of monetary policy. Princeton University Press. 